\title{
Optical Properties of the Water in Adjacent Regions of the Kuroshio*
}

\author{
Tadayoshi SASAKI ${ }^{* *}$, Noboru OKAMI ${ }^{* * *}$, Motoaki KISHINo*** \\ and Gohachiro OshiBA***
}

\begin{abstract}
Measurements of the irradiance and scalar irradiance were made using an underwater irradiance meter and an underwater scalar irradiance meter at Sagami Bay and the East China Sea, adjacent regions of the Kuroshio. From these data, we calculated the values of volume absorption function, reflectance function and diffuse attenuation functions for scalar irradiance and irradiance. It is considered that the value of $a=0.042 \sim 0.049 \mathrm{~m}^{-1}$ obtained from the upper layer in the East China Sea is that of the absorption coefficient at wave length 550 $\mathrm{m} \mu$ of the water, on which the Kuroshio has influences.
\end{abstract}

\section{Introduction}

The radiation penetrating in the ocean is influenced by the inherent optical properties of sea water at each layer in the ocean and the state of radiative transfer can be expressed by the apparent optical properties. PREISENDORFER (1958, 1961) has developed a general theory of radiative transfer in the ocean and introduced the following equations with respect to the optical properties of sea water.

Volume absorption function $a(z)$ :

$$
a(z)=\frac{1}{h} \frac{d \bar{H}(z,+)}{d z},
$$

where $\bar{H}(z,+)=H(z,+)-H(z,-)$.

Reflectance with respect to downwelling flux $R(z,-)$ :

$$
R(z,-)=\frac{H(z,+)}{H} \frac{(z,-)}{.}
$$

Diffuse attenuation function for scalar irradiance $k(z)$ :

$$
k(z)=\frac{-1}{h(z)} \frac{d h(z)}{d z} .
$$

Diffuse attenuation function for irradiance $K(z, \pm)$ :

* Received January 6, 1968

** Tokyo University of Fisheries, The Institute of Physical and Chemical Research

*** The Institute of Physical and Chemical Research

$$
K(z, \pm)=\frac{-1}{H(z, \pm)} \frac{d H(z, \pm)}{d z},
$$

where $H(z,-)$ is the downwelling irradiance at depth $z, H(z,+)$ is the upwelling irradiance at that depth and $h(z)$ is the scalar irradiance at depth $z$.

Irradirnce and scalar irradiance can be determined if the radiance distribution is known for all directions around the point of interest. TYLER et al.(1959) calculated the value of irradiance $H(z, \pm)$ and scalar irradiance $h(z)$ in Lake Pend Oreille from measurement of radiance distribution, and determined the optical properties of Lake Pend Oreille adopting equations (1) (4).

But, the value of irradiance and scalar irradiance can directly be measured by means of an irradiance meter and a scalar irradiance meter.

SMITH and TYLER (1967) measured the spectral irradiance of the upwelling and downwelling stream of radiant energy in Crater Lake using submersible spectroradiometer and calculated $K(z,-)$ and $R(z,-)$ as a function of wave length.

We measured the irradiance $H(z, \pm)$ and scalar irradiance $h(z)$ at each depth in Sagami Bay and the East China Sea by means of an underwater irradiance meter and an underwater scalar irradiance meter. And, we determined the values of $a(z), R(z,-), k(z)$ and $K(z, \pm)$ in adjacent regions of the Kuroshio. 


\section{Apparatus and methods}

Fig. 1 shows the submersible unit of a scalar irradiance meter used in the measurement (SASAKI et al., 1966).

As shown in Fig. 2, for the scalar irradiance the collector of light is composed of two hemispheres up and down. Now, the scalar irradiance is obtained from the sum of radiant fluxes collected by the hemispherical collectors. The collector of this type was used CURRIE (1961), and AUSTIN constructed similar apparatus (unpublished), which was introduced by TYLER and PREISENDORFER (1962). In our instrument, a pair of CdS photoconductive cells were placed under both collectors and the output from the light receiver was introduced to the indicator on board through a cable $150 \mathrm{~m}$ long.

In case of measuring the irradiance, two hemispherical collectors up and down were substituted by two flat plate collectors respectively and the instrument was used as irradiance meter for measuring irradiance $H(z, \pm)$. The wave length

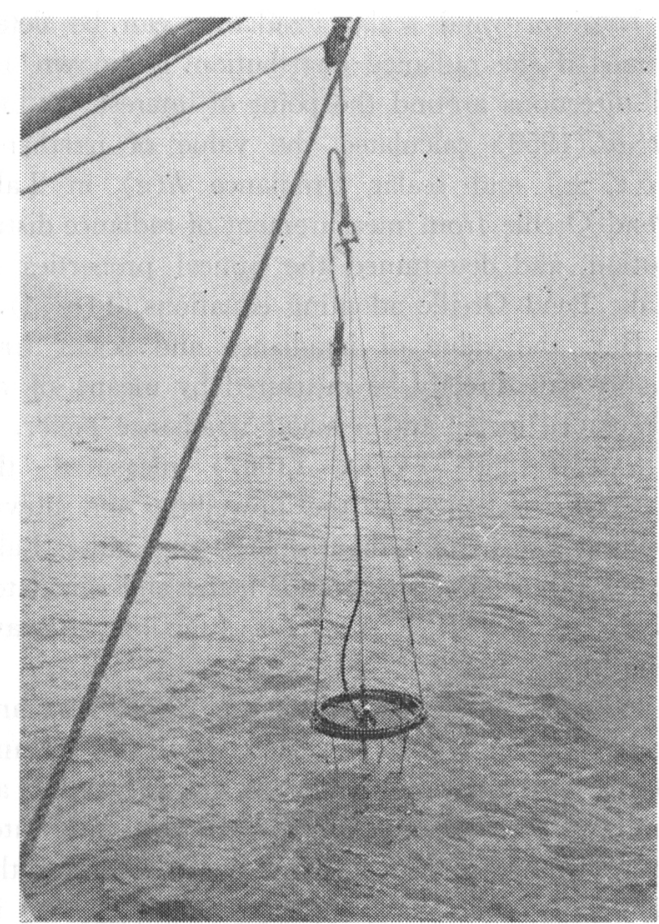

Fig. 1. Submerged unit of the scalar irradiance meter before lowering.

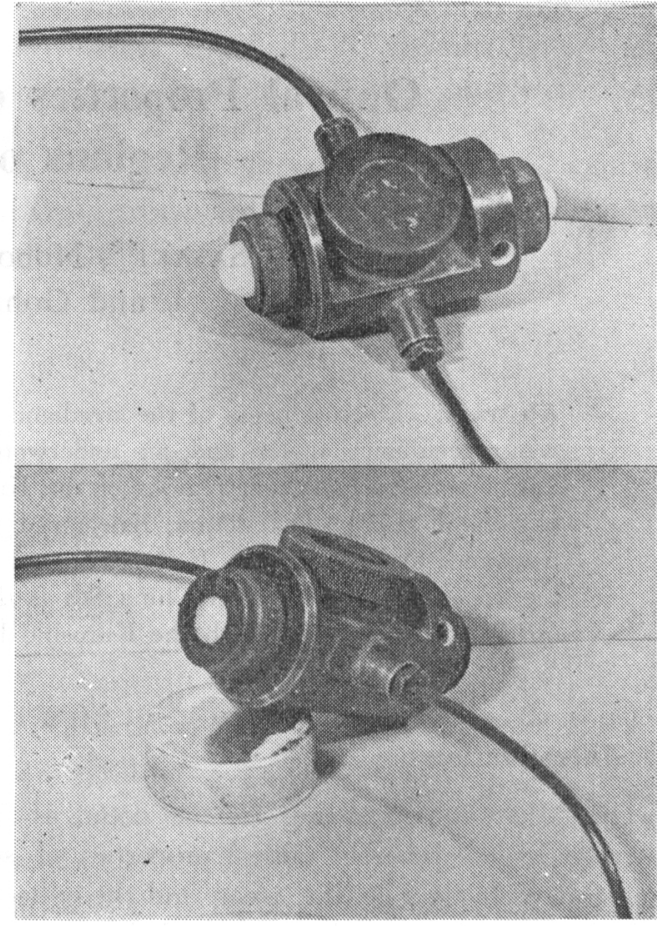

Fig. 2. The light receiver for measurement of scalar irradiance (upper) and irradiance (lower).

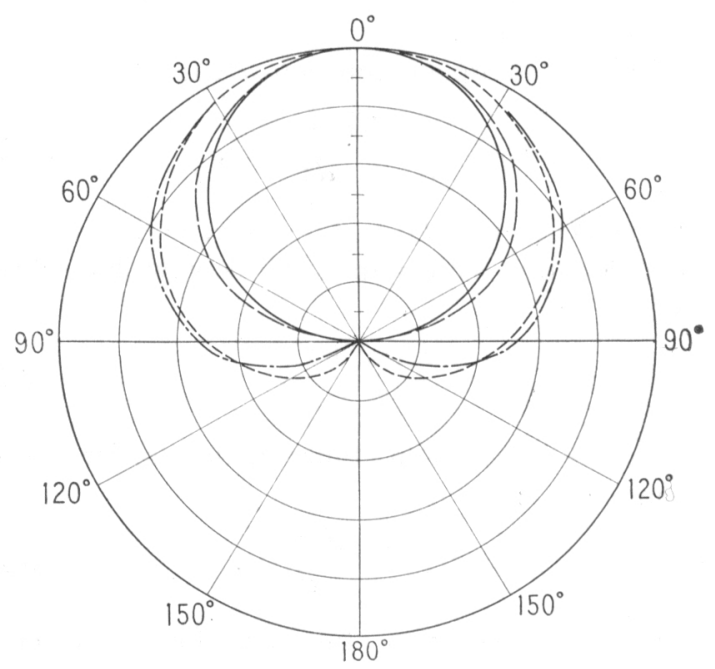

Fig. 3. Angular distribution of sensitivity of the light receiver.

$-\begin{array}{ccc}\cos \theta & \ldots 1 / 2(1+\cos \theta)\end{array}$

-- - Flat-plate collector

-.- Hemisphere collector 
to be measured was controlled by inserting a colour filter (Hooya B-56) in front of each CdS cell. The wave length of the centre of gravity is $550 \mathrm{~m} \mu$.

The light receiver for the measurement of scalar irradiance must be equally sensitive to radiation from any angle. So, when completely irradiated by a unidirectional source, the irradiance of hemisphere has to be decreased in proportion to $1 / 2(1+\cos \theta)$ as the incident radiation is moved from zenith to the equator of the hemisphere, where $\theta$ is the angle of incidence from zenith.

The dotted line of Fig. 3 is the theoretical curve showing $1 / 2(1+\cos \theta)$ and the chain line is the angular distribution of sensitivity of light receiver of the present instrument. There is some difference between two lines and when $\theta$ becomes larger, the error becomes somewhat larger.

On the other hand, as the angular distribution of sensitivity of light receiver of irradiance meter the irradiance has to be decreased in proportion to cosine of the incident angle from the zenith. The angular distribution of sensitivity of the flat plate collector is shown by the broken line, which shows a little larger than the theoretical curve shown by the solid line.

\section{Results of measurements and discussion}

Measurements of the irradiance and scalar irra- diance using the present instrument were carried out in Sagami Bay in June and in the East China Sea in July, 1967. The stations, where the measurements were carried out, are shown in Fig. 4.

The values of optical properties such as $a(z)$, $k(z), R(z,-)$ and $K(z, \pm)$ were determined from the measured data of $H(z, \pm)$ and $h(z)$ at individual stations and changes in these values with depth were investigated.

Fig. 5 shows the values measured at Stn. 1 off Ito in Sagami Bay. The values of $a(z), k(z)$ and $K(z, \pm)$ near the surface are considerably large, as this is considered to be due to that Stn. 1 is near the shore. These values decrease at first with the increase in depth but increase below the depth of $15 \mathrm{~m}$ and the peak appears in the neighbourhood of $40 \mathrm{~m}$ deep. Below this level the values gradually decrease and then become almost constant below $60 \mathrm{~m}$. As is seen from the temperature distribution at this station the peak at the depth of $40 \mathrm{~m}$ appearing in the distribution of $a(z), k(z)$ and $K(z$, $\pm)$ at this depth are due to suspended material accumulated in the neighbourhood of the thermocline, which absorbs light. On the other hand, $R(z,-)$ is roughly constant from the surface to the depth of $40 \mathrm{~m}$ and thereafter increases with the increase in depth.

Fig. 6 shows the values at Stn. 2 in the East

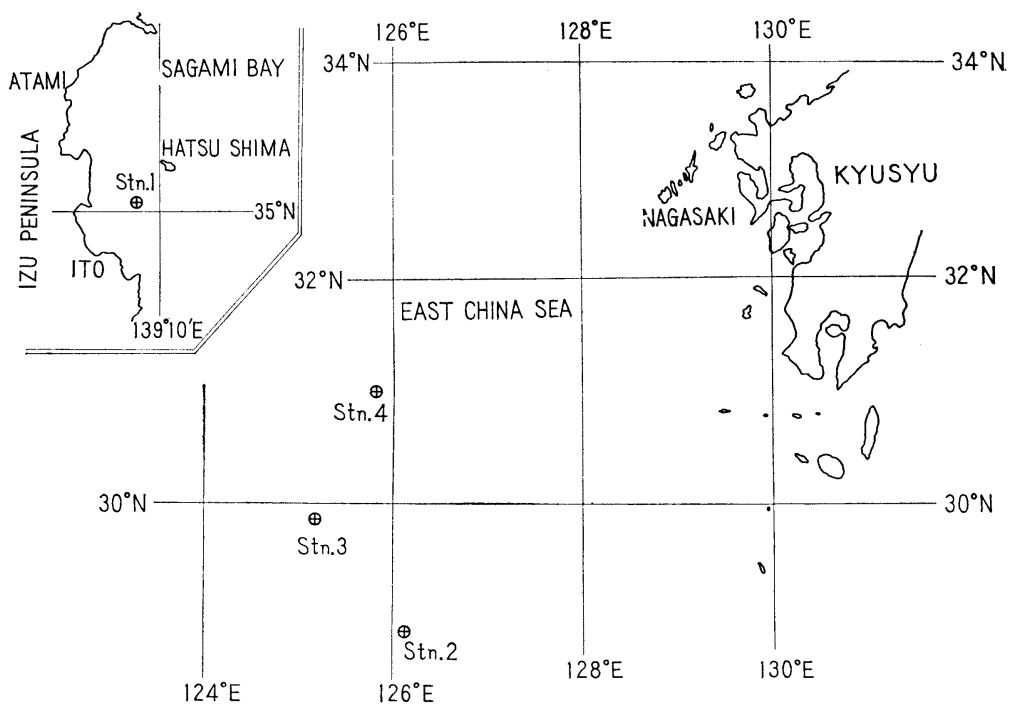

Fig. 4. Chart showing location of stations in Sagami Bay and the East China Sea where irradiance and scalar irradiance has been measured. 


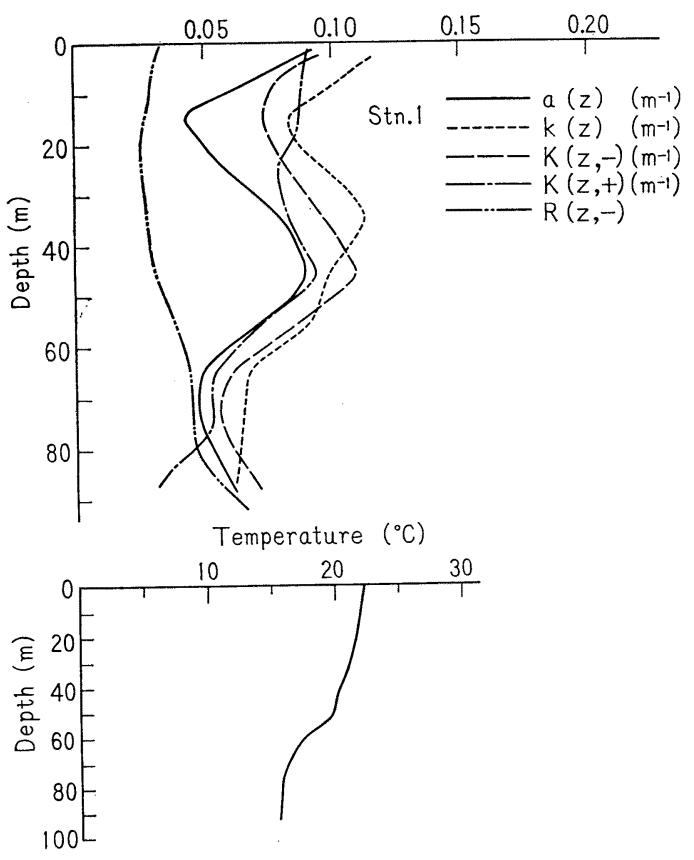

Fig. 5. Vertical distributions of $a(z), k(z)$, $K(z, \pm), R(z,-)$ and temperature at Stn. 1 in Sagami Bay.

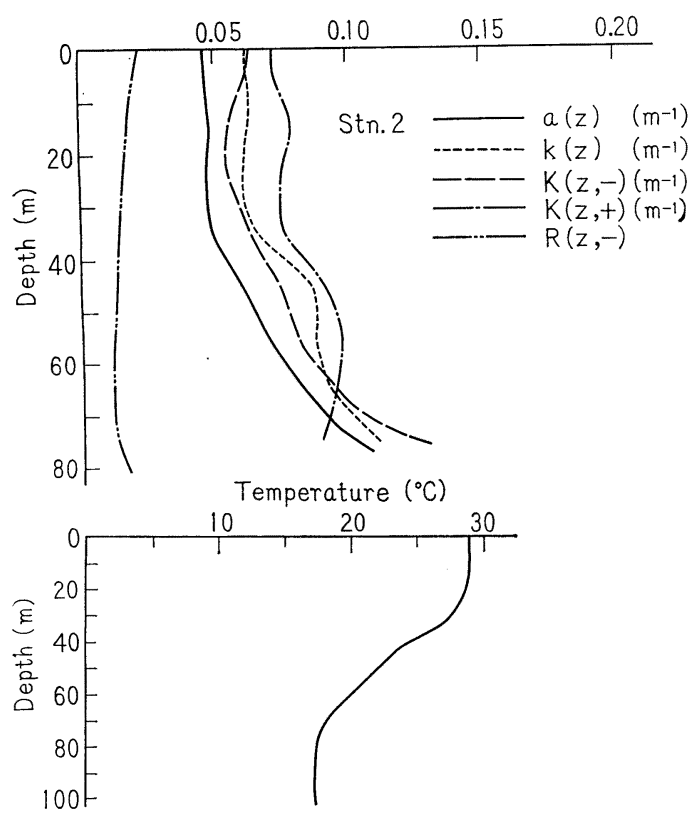

Fig. 6. Vertical distributions of $a(z), k(z)$, $K(z, \pm), R(z,-)$ and temperature at Stn. 2 in the East China Sea.
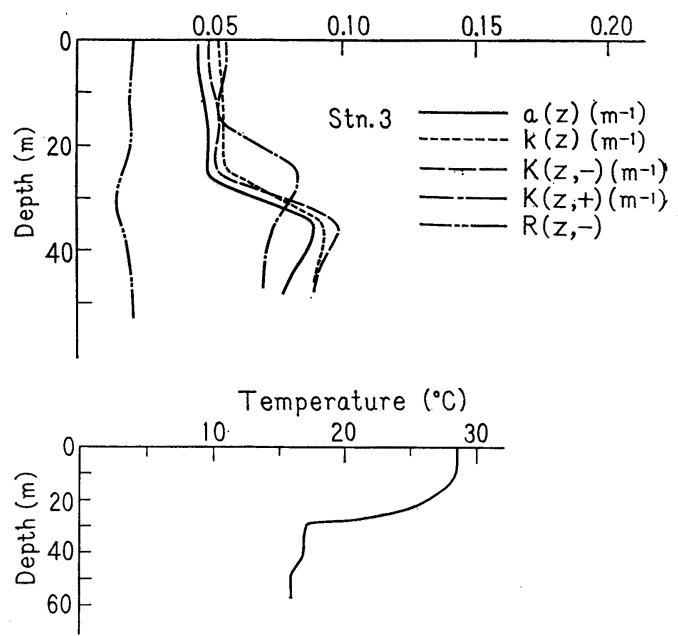

Fig. 7. Vertical distributions of $a(z), k(z)$, $K(z, \pm), R(z,-)$ and temperature at Stn. 3 in the East China Sea.

China Sea. Changes in all of $a(z), k(z)$ and $K(z, \pm)$ at this station are small from the surface to the depth of $30 \mathrm{~m}$, but thereafter increases with the increase in depth. On the other hand, $R(z,-)$ is little change with depth.

Fig. 7 shows the values at Stn. 3 in the East China Sea. The values of $a(z), k(z)$ and $K(z, \pm)$ are almost constant down to the depth of $25 \mathrm{~m}$ but rapidly increase between the levels of $25 \mathrm{~m}$ and $35 \mathrm{~m}$ and therefore little change occurs with depth. $K(z,+)$ is larger than $K(z,-)$ in the upper layer above the depth of $30 \mathrm{~m}$, but, on the contrary smaller than $K(z,-)$ in the lower layer. $R(z,-)$ decreases slightly at the depth of $30 \mathrm{~m}$ but otherwise shows an almost constant value. According to the distribution of water temperature at this station, the thermocline lies at the depth of $25 \mathrm{~m}$ and the difference in temperature between $20 \mathrm{~m}$ and $30 \mathrm{~m}$ is as much as $9^{\circ} \mathrm{C}$. Perhaps, at the depth of $25 \mathrm{~m}$, the water mass of the upper layer is different from that of the lower one. It is considered that the large difference in optical properties between the upper and lower layers separated by the depth of $25 \mathrm{~m}$ shows the difference of the water masses between these two layers.

A similar distribution is observed at Stn. 4 in the East China Sea and is shown in Fig. 8. The values of $a(z), k(z)$ and $K(z, \pm)$ of the upper layer at this station are considerably 

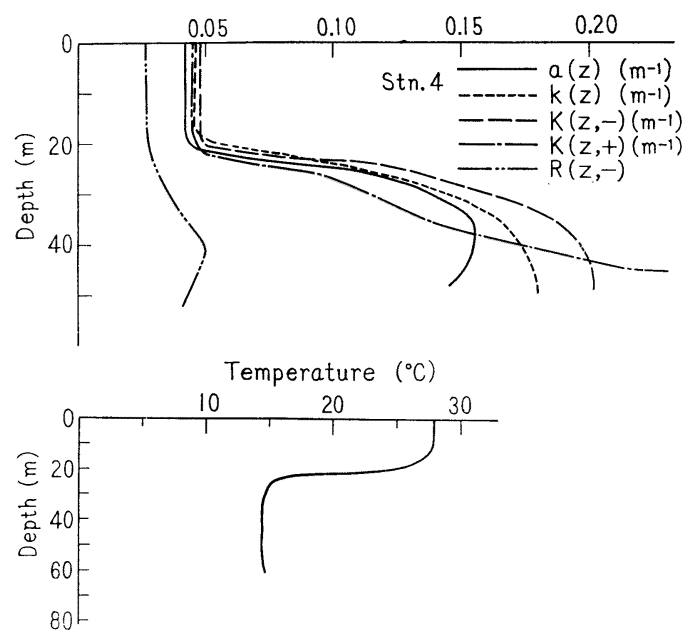

Fig. 8. Vertical distributions of $a(z), k(z)$, $K(z, \pm), R(z,-)$ and temperature at Stn. 4 in the East China Sea.

smaller than those in other regions. However, below $25 \mathrm{~m}$ those values increase rapidly. A thermocline lies in the neighbourhood of the depth of $25 \mathrm{~m}$ and the difference in water temperature between $20 \mathrm{~m}$ and $25 \mathrm{~m}$ is as much as $10^{\circ} \mathrm{C}$.

According to studies on the sea surface temperature of the East China Sea by KIKUCHI (1958), the regions of Stns. 3 and 4 in our observation era the boundary area of the Kuroshio warm water and the Yellow Sea cold water masses. Therefore, it is probable that the water mass of the upper layer is the mixed water of the Kuroshio warm water and the Yellow Sea cold water and the water mass of the lower layer is the Yellow Sea cold water. The large difference in optical properties between the upper and lower layers as described above may perhaps be due to this.

The values of volume absorption function $a(z)$ and reflectance $R(z,-)$ of these stations and those in Lake Pend Oreille obtained by TYLER and PREISENDORFER (1962) are shown in Table 1.

The value of $a(z)$ of the surface water in the East China Sea is smaller than that of the surface water in Sagami Bay or Lake Pend Oreille. However, the value of $a(z)$ of the lower layer water in the East China Sea is larger than that of the lower water in Sagami Bay and approximately similar to that of Lake Pend Oreille. There is not much difference between the value of $a(z)$ of the upper layer water in the East China Sea and the value of absorption coefficierrt for distilled water, $a=0.037 \mathrm{~m}^{-1}$, obtained by HUlburT (1945). From the structure of water masses in this area as described above, we consider that the value of $a=0.042 \sim 0.049 \mathrm{~m}^{-1}$ obtained from the upper layer in the East China Sea is that of the absorption coefficient at wave length $550 \mathrm{~m} \mu$ of the water, on which the Kuroshio has influences. On the other hand, we consider that the large value of $a(z)$ of the lower layer in the East China Sea may have been caused by dissolved materials in the cold water of the Yellow Sea known as "yellow sub-

Table 1 . The values of the volume absorption function $a(z)$ and the reflectance function $R(z,-)$ for various depths in Sagami Bay and the East China Sea.

\begin{tabular}{|c|c|c|c|c|c|c|c|c|c|c|c|}
\hline \multirow{2}{*}{$\begin{array}{c}\text { Depth } \\
\text { (m) }\end{array}$} & \multicolumn{2}{|c|}{ Stn. 1} & \multicolumn{2}{|c|}{ Stn. 2} & \multicolumn{2}{|c|}{ Stn. 3} & \multicolumn{2}{|c|}{ Stn. 4} & \multirow{2}{*}{$\begin{array}{c}\text { Depth } \\
\text { (m) }\end{array}$} & \multicolumn{2}{|c|}{ Lake Pend Oreille* } \\
\hline & $a\left(m^{-1}\right)$ & $R$ & $a\left(m^{-1}\right)$ & $R$ & $a\left(m^{-1}\right)$ & $R$ & $a\left(m^{-1}\right)$ & $R$ & & $a\left(m^{-1}\right)$ & $R$ \\
\hline 5 & 0.084 & 0.031 & 0.047 & 0.020 & 0.044 & 0.021 & 0.042 & 0.025 & 4.24 & & 0.0215 \\
\hline 15 & 0.044 & 0.027 & 0.049 & 0.018 & 0.049 & 0.021 & 0.042 & 0.026 & 10.4 & 0.115 & 0.0184 \\
\hline 25 & 0.059 & 0.026 & 0.047 & 0.016 & 0.049 & 0.018 & 0.089 & 0.030 & 16.6 & 0.118 & 0.0204 \\
\hline 35 & 0.081 & 0.028 & 0.049 & 0.014 & 0.079 & 0.017 & 0.155 & 0.042 & 29.0 & 0.117 & 0.0227 \\
\hline 45 & 0.090 & 0.032 & 0.060 & 0.013 & 0.070 & 0.020 & 0.150 & 0.043 & 41.3 & 0.117 & 0.0235 \\
\hline 55 & 0.073 & 0.038 & 0.069 & 0.011 & & & & & 53.7 & 0.112 & 0.0234 \\
\hline 65 & 0.050 & 0.044 & 0.083 & 0.011 & & & & & 66.1 & & 0.0190 \\
\hline 75 & 0.049 & 0.047 & 0.103 & 0.013 & & & & & * After & TYLER & \\
\hline 85 & 0.058 & 0.055 & & & & & & & $\mathrm{PR}$ & SENDOF & $R(1962)$ \\
\hline
\end{tabular}


stance" having strong absorption in the blue region of the spectrum.

Little difference is observed in the value of $R(z,-)$ between Sagami Bay, the East China Sea and Lake Pend Oreille. In fact, in most natural waters the value of $R(z,-)$ for green light is usually found in the neighbourhood of 0.02 . The value of $R(z,-)$ measured in the present research is not so much different from 0.02 .

Among inherent optical properties there is the total scattering function $s(z)$ in addition to the volume absorption function $a(z)$ determined in the present research. The total scattering function $s(z)$ can be found by calculation from the measurement of volume scattering function $\sigma(\theta)$ or determined by subtracting volume absorption function $a(z)$ from attenuation function $\alpha(z)$ measured by means of a beam transmittance meter. We are now attempting to measure optical properties in several regions in the Kuroshio using the latter method.

\section{Acknowledgements}

The authors wish to express their hearty thanks to Mr. Keijiro OzAwA, the captain of the training ship Umitaka-Maru of Tokyo University of Fisheries, and the officers and crew of UmitakaMaru, for their collaboration with them throughout the course of the East China Sea observation. Thanks are also due to Dr. Makoto IsHINO, Tokyo University of Fisheries, who gave us an mportant suggestion on the oceanographic condi- tions of the East China Sea.

\section{References}

CURRIE, R. I. (1961): Scalar irradiance as a parameter in phytoplankton photosynthesis and a proposed method for its measurement. U.G.G.I. Monogr., 10, 107-112.

Hulburt, E. O. (1945): Optics of distilled and natural water. Jour. Opt. Soc. Amer., 35 (11), 698-705.

KIKUCHI, S. (1958): Research on the sea surface temperature of the East China Sea. (1) Characters on the normal condition. Jour. Met. Res. JMA, 11, 169-183.

PREISENDORFER, R. W. (1958): Directly observable quantities for light fields in natural hydrosols. Scripps Inst. Oceanogr., Univ. Calif. Ref. 58-46, pp. 29.

Preisendorfer, R. W. (1961): Application of radiative transfer theory to light measurement in the sea. U.G.G.I. Monogr., 10, 11-30.

SASAKI, T., G. OSHIBA and M. KISHINo (1966): A $4 \pi$-underwater irradiance meter. Jour. Oceanogr. Soc. Japan, 22 (4), 123-128.

SMITH, R. C. and J. E. TYleR (1967): Optical properties of clear natural water. Jour. Opt. Soc. Amer., 57 (5), 589-595.

TYlER, J. E., W. H. RICHARDSON and R. W. Holmes (1959): Method for obtaining the optical properties of large bodies of water. Jour. Geophys. Res., 64 (6), 667-673.

TYlER, J. E. and R. W. PREISENDORFER (1962): The Sea. Vol. 1, p. 442 and p. 446, In. M. N. Hill, Intersci. Pub., John Wiley \& Sons, New York and London.

\section{黒潮隣接海域の海水の光学的性質について \\ 佐々木忠義 岡見 登 岸野元彰大柴五八郎}

要旨 水中放射照度計と水中スカラ一放射照度計を用い て, 黒潮隣接海域の相模湾と東シナ海で放射照度とスカ ラ一放射照度の測定を行なった. これらの測定結果から 吸収関数 $a(z)$, 反射率関数 $R(z,-)$ および拡散光につ いての消散関数 $K(z, \pm)$ と $k(z)$ を計算した.

東シナ海の上層で得た吸収係数 $a=0.042 \sim 0.049 \mathrm{~m}^{-1}$
の值は黒潮の影響を受けた水の波長 $550 \mathrm{~m} \mu$ に颃ける吸 収係数の值であると考えられる. 一方, 下層の水は黄海 冷水で, 得られた $a(z)$ の大きな值は海水中に溶存して いる “yellow substance”のような青色光を強く吸収す る物質に起因しているのではないかと考える. 